\title{
Christian Stettler
}

\section{Das letzte Gericht}

\section{Studien zur Endgerichtserwartung von den Schriftpropheten bis Jesus}

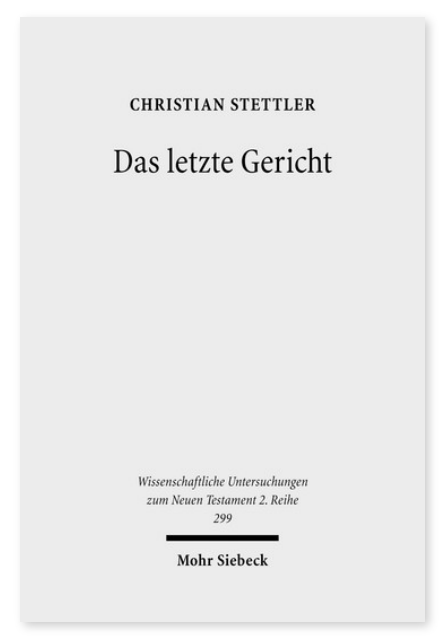

2011. XV, 321 Seiten. WUNT II 299

ISBN 978-3-16-151642-9

DOI 10.1628/978-3-16-151642-9

eBook PDF

ISBN 978-3-16-150512-6

fadengeheftete Broschur $94,00 €$
Christian Stettler zeichnet die Entfaltung der Endgerichtserwartung von den Schriftpropheten bis zu Jesus nach. Dabei wird deutlich, dass die Gerichtserwartung im Weltordnungsdenken und in der Königsideologie wurzelt und dass der Fülle von Gerichtsmotiven seit der Exilszeit ein gemeinsames Thema zugrunde liegt: die Erwartung, dass JHWH durch das Endgericht seine Königsherrschaft universal aufrichten wird und dass nur die an der Gottesherrschaft teilhaben werden, die gemäß der Tora »gerecht« sind. Die Frage, wer die gemäß der Tora Gerechten sind bzw. wie man diese Gerechtigkeit erlangt, wird in den verschiedenen frühjüdischen Strömungen und Texten unterschiedlich beantwortet. Hierdurch ergibt sich eine differenzierte Kritik an E. P. Sanders' einflussreicher Bundesnomismus-These. - Johannes der Täufer und Jesus stehen in der apokalyptischen Tradition. Neu ist bei Jesus, dass er seine eigene Person und sein eigenes Todesgeschick in enge Verbindung mit der Gerichtserwartung bringt.

Christian Stettler Geboren 1966; Studium der Ev. Theologie; 1992 Ordination; 2000 Promotion; seit 2007 Pfarrer in der Schweiz; 2014 Habilitation; seit 2014 Privatdozent für Neues Testament an der Universität Zürich und Titularprofessor für Neues Testament und Antikes Judentum an der Staatsunabhängigen Theologischen Hochschule Basel.

Jetzt bestellen:

https://mohrsiebeck.com/buch/das-letzte-gericht-9783161516429?no_cache=1

order@mohrsiebeck.com

Telefon: +49 (0)7071-923-17

Telefax: $+49(0) 7071-51104$ 